\title{
Hydrographic and biological controls in two subarctic fjords: an environmental case study of how climate change could impact phytoplankton communities
}

\author{
Antonietta Quigg ${ }^{1,2, *}$, Clifton C. Nunnally ${ }^{2}$, Allison S. McInnes ${ }^{2}$, Shelton Gay ${ }^{2}$, \\ Gilbert T. Rowe ${ }^{1,2}$, Timothy M. Dellapenna ${ }^{2,3}$, Randall W. Davis ${ }^{1,4}$ \\ ${ }^{1}$ Department of Marine Biology, and ${ }^{3}$ Department of Marine Science, Texas A\&M University at Galveston, \\ 200 Seawolf Parkway, Galveston, Texas 77553, USA \\ ${ }^{2}$ Department of Oceanography, and ${ }^{4}$ Department of Wildlife and Fisheries Science, Texas A\&M University, College Station, \\ Texas 77843, USA
}

\begin{abstract}
Over the past $50 \mathrm{yr}$, Alaska has warmed at more than twice the rate of the rest of the United States so that climate change impacts are much more pronounced in this region. Simpson and Sheep Bays are pristine fjords in Prince William Sound which differ significantly in terms of size and bathymetry, watershed topography and presence of alpine glaciers. During summers in 2006 to 2008, we investigated the relationship between hydrography and phytoplankton ecology. We found phytoplankton standing stocks and productivity were higher in Simpson relative to Sheep Bay. Phytoplankton physiology (measured with a fluorescence induction and relaxation system) was not significantly different $(\mathrm{p}>0.05)$ in the 2 fjords: $F_{\mathrm{V}} / F_{\mathrm{M}}=0.32$ to $0.67, \sigma_{\mathrm{PSII}}=141$ to $391 \AA^{2}$ quanta $^{-1}, \tau_{\mathrm{Qa}}=125$ to $1020 \mu \mathrm{s}$, and $p=0.06$ to 0.39 . Resource (also known as nutrient) limitation assays revealed a gradient of nutrient co-limitation (NSi to NP, respectively) from the delta to the mouth in Simpson Bay. Phytoplankton dynamics were found to be driven by wind mixing and nutrient upwelling which fueled productivity in the upper water column. A comparison of temperature/salinity profiles measured in the present study with those in 1996/1997 revealed a decadal change in hydrography. Both fjords exhibited deep vertical gradients indicative of moderate vertical mixing in 1996/1997, while those measured in 2007/2008 were shallow, with significant stratification. These changes in hydrography, associated with climate change at these high latitudes, will likely lower phytoplankton productivity due to decreased reintroduction of nutrients to surface waters. Consequences to higher trophic levels of reduced food supply require further investigation, including food web and modeling studies.
\end{abstract}

KEY WORDS: Phytoplankton · Fjords · Alaska $\cdot$ Chlorophyll fluorescence $\cdot$ Primary productivity Nutrients $\cdot$ Resource limitation assays $\cdot$ Climate change

\section{INTRODUCTION}

Over the past $50 \mathrm{yr}$, the Alaskan climate has warmed at more than twice the rate of the rest of the United States (US Global Change Research Program 2009). As a result, climate change impacts are much more pronounced in this region than at lower latitudes (Julius \& West 2008, US Global Change
Research Program 2009, Haufler et al. 2010). These include changes in sea level and storms (intensity, frequency), ocean acidification and warming, retreating glaciers, changing precipitation (amount, pattern), and freshwater runoff. More than $5600 \mathrm{~km}$ of coastline, consisting of $100 \mathrm{~s}$ of islands, fjords, and bays, formed within Prince William Sound (PWS) in south central Alaska at the end of the last glaciation 
$\sim 15000$ yr ago. The highly productive coastal rainforests in PWS intermingle with marine and freshwater aquatic environments, resulting in a highly diverse and productive natural environment teaming with fin fish, shellfish, mammals, and shorebirds. Because of the difficulties of conducting field studies in much of this remote area, the oceanography and marine ecology remains poorly described.

High summer biological productivity in this region is thought to be paradoxical because of seasonally persistent downwelling conditions that prevail along the Gulf of Alaska from fall through spring (Royer 2005, Spies 2007). A recent report (PICES 2004) has identified other potential sources of nutrients as processes that include relaxation and/or reversal of downwelling into coastal upwelling during summer to early fall, eddies, and onshore Ekman transport processes. A subsurface chlorophyll (chl) maximum late in the summer identified over the deeper portions of the Gulf of Alaska shelf suggests vertical mixing events may also introduce nutrients to upper layers (Sambrotto \& Lorenzen 1986). The linkage between the physical processes operating in PWS and those within small, protected basins, such as subarctic fjords and bays is unresolved. Some decoupling is evident in both the hydrography (Gay \& Vaughan 2001) and the timing of the spring phytoplankton bloom (Eslinger et al. 2001) which begins in fjords or bays and then extends offshore into PWS and then to the Gulf of Alaska. In addition, there is uncertainty regarding the relative contributions of local verses allochthonous (i.e. advected) sources of nutrients within near-shore systems. It is known, however, that the increased concentration of phytoplankton biomass associated with large spring and frequent summer blooms in subarctic areas represents an essential nutritional supply for higher trophic levels (Ziemann et al. 1990, Eslinger et al. 2001, A. S. McInnes et al. unpubl. data).

Large spring phytoplankton blooms are typically observed in early April in PWS (e.g. Laws et al. 1988, Ziemann et al. 1990, Horner et al. 1997, Spies 2007), with nutrient (usually nitrogen) limitation of primary production reported during the summer months (Goering et al. 1973, Ziemann et al. 1990, Eslinger et al. 2001). Some of these blooms involve harmful algal species such as Alexandrium catenella, a dinoflagellate that produces paralytic shellfish poisoning, and Pseudonitzschia spp., a diatom that produces domoic acid poisoning (Horner et al. 1997). Dominant phytoplankton genera in summer blooms generally include diatom genera such as Thalassiosira, Skeletonema, and Chaetoceros (Waite et al. 1992) and the dinoflagellate Noctiluca (A. S. McInnes et al. unpubl. data). Phytoplankton standing stocks can be as high

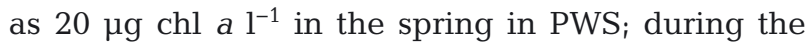

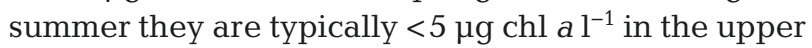
$10 \mathrm{~m}$ of the water column (Ziemann et al. 1990, Eslinger et al. 2001).

The aim of this study was to examine the relationship between the hydrography and phytoplankton (physiology, community, production) in 2 subarctic fjords within PWS, Alaska (Fig. 1). Simpson Bay was studied from 2006 to 2008 and Sheep Bay only in 2006. During cruises each summer, we measured environmental variables including salinity, temperature, turbidity, chl $a$, dissolved oxygen, and Secchi depth. A fluorescence induction and relaxation (FIRe) fluorometer was used to (1) measure phytoplankton physiology from water samples collected on fine horizontal and vertical scales (all summers), (2) estimate primary productivity in each fjord (in 2006), and (3) measure the response of the phytoplankton community to nutrient additions (in 2008). This paper also includes temperature and salinity data collected at Simpson and Sheep Bays in 1996/1997 during the Sound Ecosystem Assessment program (Gay \& Vaughan 2001), and temperature, salinity, fluorescence, and turbidity data collected at Simpson in 2008 (Gay 2011). While we focused on different aspects of the hydrography and phytoplankton activity each summer, the cumulative effort enabled us to test a series of hypotheses to develop an understanding of the factors regulating primary productivity.

\section{MATERIALS AND METHODS}

\section{Study area}

In the remote south central portion of PWS, Alaska, USA (Fig. 1) is a campsite (3 tents, 1 field house) operated by Texas A\&M University at Galveston that is only accessible by boat or float plane. Situated at Alice Cove, the campsite is located between Simpson and Sheep Bays. Simpson Bay (fjord basin $\sim 21 \mathrm{~km}^{2}$; watershed $170 \mathrm{~km}^{2}$ ) is partially enclosed and generally deeper (Gay \& Vaughan 2001, Noll et al. 2009) than Sheep Bay (fjord basin $\sim 42 \mathrm{~km}^{2}$; watershed $95 \mathrm{~km}^{2}$ ) which is open but not protected from the prevailing winds, is shallow, and has numerous rocky outcroppings.

Simpson Bay can be divided into 3 basins according to Noll et al. (2009) (Fig. 1). In the northern arm, there is a wide, shallow delta which introduces alpine glacial freshwater runoff, particularly after 

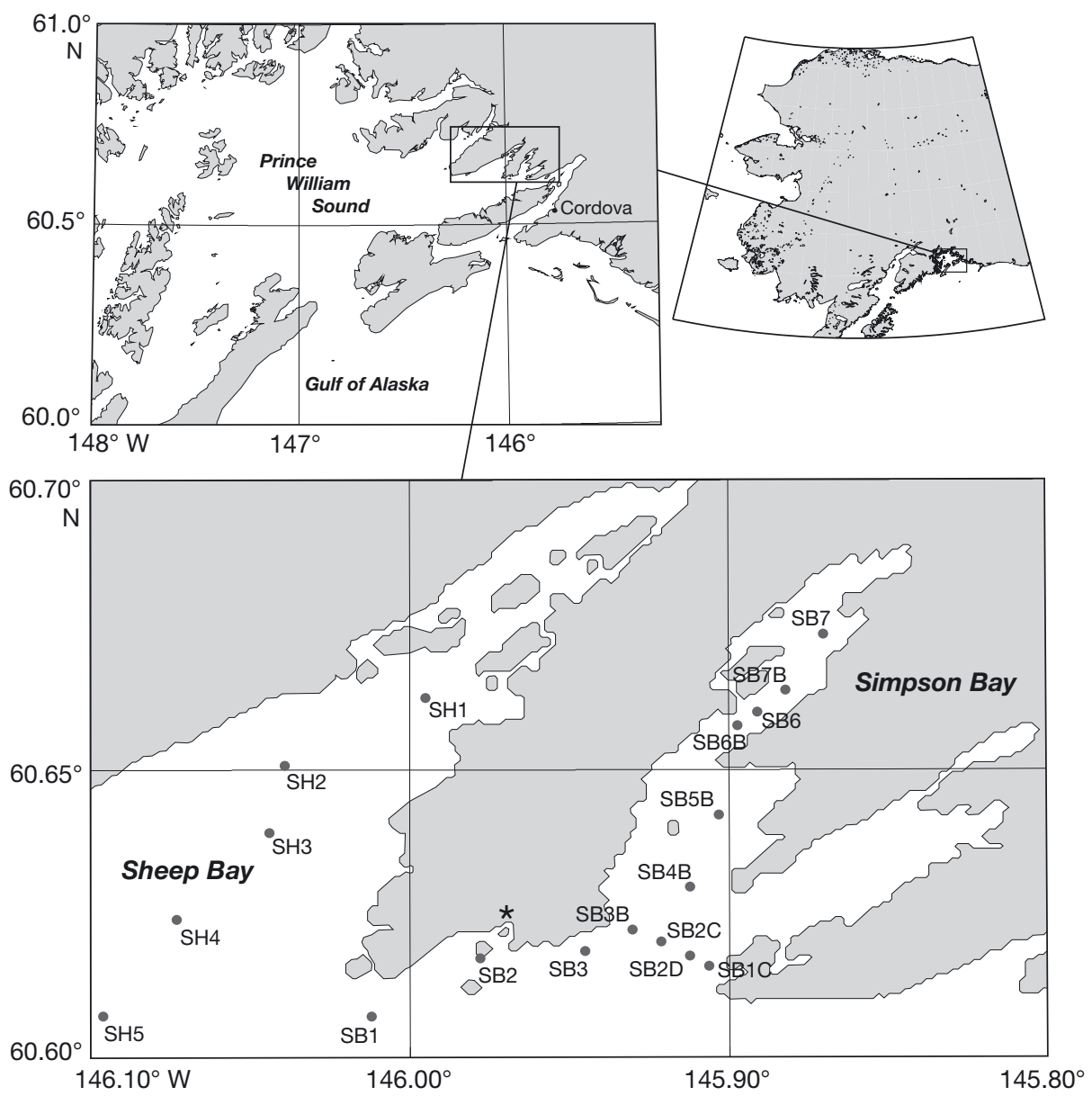

Fig. 1. Location of Simpson and Sheep Bay in Prince William Sound, south central Alaska. The research station at Alice Cove (star) is located midway between these 2 fjords at $60.62^{\circ} \mathrm{N}, \quad 145.97^{\circ} \mathrm{W}$. Station codes correspond to locations for hydrographic and phytoplankton specific sampling described in the relevant sections snow melts and heavy rain. The river delta opens into the northern arm (30 m average depth), which reaches a maximum depth of $\sim 80 \mathrm{~m}$ north of a shallow $(<10 \mathrm{~m})$ reef that partially isolates it from the western basin (Fig. 1). The western basin is relatively shallow (40 to $60 \mathrm{~m}$ ), while the eastern basin reaches $>80 \mathrm{~m}$ near the entrance and increases to $>125 \mathrm{~m}$ at the mouth which opens to Orca Bay. There are numerous waterfalls and streams located along the shores; this supply of freshwater is important to the hydrology in Simpson Bay (Gay \& Vaughan 2001). Sheep Bay has considerably fewer alpine glacial inputs, with the primary source of runoff at the head. In contrast to Simpson, it is buffered by a small, estuarine lagoon (Fig. 1).

\section{Water column profiles in Simpson Bay}

Vertical profiles of temperature, salinity, fluorescence, and turbidity were measured at stations within Simpson Bay in 2007 and 2008 (Fig. 1). Salin- ity will be presented using the unit-less practical salinity unit (PSU) scale throughout. The data were collected using a SeaBird SBE19plus conductivity, temperature, and depth (CTD) profiler with a Wet Labs ECO fluorometer-turbidimeter attached as an auxiliary sensor package. Both instruments were calibrated by the respective manufacturers. CTD data were collected synoptically with an acoustic doppler current profiler (ADCP). Approximately 12 sets of ADCP transects were surveyed per cruise, with hydrography measured on every other run, resulting in hydrographic profiles collected over semidiurnal to diurnal tidal periods. Given that profiles were not qualitatively different between years (2007 and 2008) and that phytoplankton measurements were typically performed in June each year, we include only water quality data collected in June 2007 in the present paper; all other data are presented by Gay (2011). We also include data collected in 1996 from these 2 bays, using similar instrumentation as in 2007 . The difference between the data sets is that 1996 profiles represent single samples measured at stations shown 
in Fig. 1, whereas the 2007 data were averaged over a full tidal cycle (see above).

\section{Survey cruises and water quality in both bays}

Cruises were conducted between 08:00 and 12:00 h local time in small skiffs. Sampling was not timed to correspond to a particular tidal stage, and, consequently, samples were collected during both ebb and flood tides at all tidal sites. The tidal range in summer as determined from the Cordova district tide table includes low tides of -0.92 to $1.52 \mathrm{~m}$ and high tides of 3.6 to $5.4 \mathrm{~m}$. During each cruise in 2006, stations were chosen randomly, about 200 to $300 \mathrm{~m}$ apart, to obtain comprehensive spatial coverage in both fjords. Sampling in 2007 and 2008 was focused on specific locations (see Fig. 1). A mini sonde hydrolab was used to measure temperature, salinity, dissolved oxygen, and depth, at $2 \mathrm{~m}$ intervals from the surface (e.g. 0.3, 2, 4, 6, 8, and $10 \mathrm{~m}$ ). Water samples were collected for FIRe, chl $a$, and other analyses in 11 acidwashed bottles at each station. A 51 Niskin bottle was used to collect water samples from greater depths. All water samples were stored in the dark at ambient temperatures $\left(\mathrm{ca} .12^{\circ} \mathrm{C}\right.$ ) until returning to the campsite. The hydrolab was calibrated prior to and after the cruises; there was $<5 \%$ instrument drift. Findings for all parameters are presented as averages $( \pm \mathrm{SD})$.

\section{Fluorescence measurements}

A FIRe (Satlantic Instruments) fluorometer (Gorbunov \& Falkowski 2005) was used to measure physiological responses of phytoplankton in water samples $(3 \mathrm{ml})$ from each station and depth. All measurements were performed using a gain of 2400 and 40 acquisitions. We used only information collected from the single turnover component of the transient (see Kolber et al. 1998, Kromkamp \& Forster 2003); specifically, the minimal and maximal fluorescence yields ( $F_{\mathrm{O}}$ and $F_{\mathrm{M}}$, respectively) were obtained with dark-acclimated (min. $30 \mathrm{~min}$ ) samples. Variable fluorescence $\left(F_{\mathrm{V}}\right)$ was calculated as the difference between these parameters $\left(F_{M}-F_{O}\right)$. The efficiency of Photosystem II (PSII) defined as the maximum change in the quantum yield of photochemistry was calculated as $F_{\mathrm{V}} / F_{\mathrm{M}}=\left(F_{\mathrm{M}}-F_{\mathrm{O}}\right) / F_{\mathrm{M}}$; this is best used as an indicator of nutrient stress when phytoplankton growth is unbalanced, such as in the natural environment (Parkhill et al. 2001). Fil- tered seawater $(0.7 \mu \mathrm{m})$ collected from each sample was used to correct for interference from background fluorescence. These sample blanks were subtracted from the values of $F_{\mathrm{O}}$ and $F_{\mathrm{M}}$ (Cullen \& Davis 2003) prior to calculation of $F_{\mathrm{V}} / F_{\mathrm{M}}$. The blank contributed to $<8 \%$ of the signal; this is small based on the findings of Cullen \& Davis (2003).

The functional absorption cross-section for PSII $\left(\sigma_{\text {PSII }} \AA^{2}\right.$ quanta $\left.^{-1}\right)$, the minimum turnover time of electron transfer between reaction centers $\left(\tau_{\mathrm{PSII}} ; \mu \mathrm{s}\right)$, and the connectivity factor $(p)$ were also derived. Changes in cellular pigment concentrations and the efficiency of energy transfer from pigments to PSII reaction centers are reflected in $\sigma_{\text {PSII }}$, making it subject to both light and nutrient availability (Kolber et al. 1998). $\tau_{\mathrm{Qa}}$ reflects the efficiency of the photosynthetic apparatus (Kolber et al. 1998, Gorbunov et al. 2000), with faster time constants for more effective photosynthetic electron transfer on the acceptor side of PSII. The probability of energy transfer between PSII reaction centers is a function of the connectivity, with higher $p$ values indicating higher probabilities of electron transfer and therefore ample light or nutrient replete conditions and a more efficient photosynthetic apparatus (Kolber et al. 1998).

The FIRe fluorometer design (Gorbunov \& Falkowski 2005) is based on the fast repetition rate fluorometer (FRRF; Kolber et al. 1998). Unlike the FRRF, the FIRe is a bench top instrument, has neither light/ dark chambers nor a photosynthetically active radiation sensor, but it does come with an external actinic light source that can be used to deliver a saturating pulse of actinic light so that post-illumination fluorescence quotients can be derived. For these reasons, we were not able to use the FIRe to measure in situ primary production (see Suggett et al. 2010). In this paper, we measured discrete samples to calculate the electron transport rate $\left(\mathrm{ETR}_{\mathrm{PSII}}\right)$ and then estimate integrated production rates.

After 30 min dark acclimation, a series of 11 actinic light intensities between 12 and 1650 umol photons $\mathrm{m}^{-2} \mathrm{~s}^{-1}$ was applied to each sample. The data were fitted to the model of Kolber et al. (1998), including parameters such as maximum and minimal fluorescence, effective PSII cross-section $\left(\sigma_{\text {PSII }}\right)$ and connectivity $(p)$. These parameters were used to calculate $\mathrm{ETR}_{\mathrm{PSII}}$ from $\sigma_{\mathrm{PSII}}\left(F_{\mathrm{Q}}{ }^{\prime} / F_{\mathrm{V}}{ }^{\prime}\right) /\left(F_{\mathrm{V}} / F_{\mathrm{M}}\right) E_{\text {, where fluores- }}$ cence parameters are measured in the light, $F_{\mathrm{Q}}{ }^{\prime}=$ $\left(F_{M^{\prime}}-F^{\prime}\right)$ and $E=$ light intensity according to Suggett et al. (2010), and more recently Quigg et al. (2012). The specific absorption of PSII ( $\left.a^{*}{ }_{\text {PSII }}\right)$ was calculated as $\left[\sigma_{\mathrm{PSII}}\left(\mathrm{RC}_{\mathrm{PSII}} / \mathrm{chl} a\right)\right] /\left(F_{\mathrm{V}}{ }^{\prime} / F_{\mathrm{M}^{\prime}}\right)$, where $\mathrm{RC}_{\mathrm{PSII}} / \mathrm{chl} a$ is equal to 0.002 (Suggett et al. 2010). 


\section{Chl a analysis}

Water samples were filtered under low light conditions and low vacuum pressure $(<130 \mathrm{kPa})$ onto Whatman GF/F filters, folded, and frozen at $-20^{\circ} \mathrm{C}$. Samples were shipped on dry ice and stored at $-80^{\circ} \mathrm{C}$. Chl a was extracted with $100 \%$ acetone for $24 \mathrm{~h}$ at $-4^{\circ} \mathrm{C}$ in darkness. Just prior to measurement in the Turner 10AU fluorometer, samples were diluted to $90 \%$ acetone with distilled water and centrifuged to remove particulates. Samples were acidified with $10 \% \mathrm{HCl}$ to also measure phaeophytin concentrations, and then corrected chl a concentrations were calculated according to Arar \& Collins (1997).

\section{Pigment analysis (only 2008)}

Water samples were collected and processed as described above for chl a except that pigments were extracted and processed according to the protocols of Dr. J. Pinckney (University of South Carolina; http:// ww2.biol.sc.edu/ jpinckney/). The sample analysis protocol has been described by Dorado et al. (2012). We only considered the major pigments: fucoxanthin, peridinin, zeaxanthin, chl $b$, and prasinoxanthin, which we used as representative of diatoms, dinoflagellates, cyanobacteria, and green algae, respectively (Dorado et al. 2012, A. S. McInnes et al. unpubl. data).

\section{Nutrient analysis (only 2008)}

Filtrate from water samples was stored frozen until analysis of inorganic phosphorus $(\mathrm{P})$, nitrite $\left(\mathrm{NO}_{2}{ }^{-}\right)$, nitrate $\left(\mathrm{NO}_{3}{ }^{-}\right)$, ammonium $\left(\mathrm{NH}_{4}{ }^{+}\right)$, and silicate (Si) concentrations $(\mu \mathrm{M})$ by the Geochemical and Environmental Research Group at Texas A\&M University. Dissolved inorganic nitrogen (DIN) concentrations were calculated by summing nitrite, nitrate, and ammonium concentrations. The analytical detection limits were $0.025 \mu \mathrm{M}$ for $\mathrm{P}, 0.012 \mu \mathrm{M}$ for nitrite, $0.04 \mu \mathrm{M}$ for nitrate, $0.057 \mu \mathrm{M}$ for ammonium, and $0.13 \mu \mathrm{M}$ for silicate. (Note: Although we collected and shipped samples for nutrient analysis each year, we only received them still frozen in 2008.)

\section{Resource limitation assays (only 2008)}

To determine if nutrient(s) or light were limiting primary productivity, resource limitation assays (RLA) were performed using previously described procedures (Fisher et al. 1999, Quigg et al. 2008, 2011) at 4 stations (see Table 2). Within 2 h of surface water collection, an 'initial' sample was taken to measure FIRe parameters, chl $a$, and nutrient concentrations.

Water was divided amongst 24 acid-washed 11 clear polycarbonate bottles. Treatments (performed in triplicate) in the multi-factorial experimental design were control ( $\mathrm{C}_{\text {; }}$ no addition), $+\mathrm{N}(+30 \mu \mathrm{M}$ $\left.\mathrm{NO}_{3}{ }^{-}\right),+\mathrm{P}\left(+2 \mu \mathrm{M} \mathrm{PO}_{4}{ }^{3-}\right),+\mathrm{Si}\left(+30 \mu \mathrm{M} \mathrm{SiO}_{4}{ }^{4-}\right),+\mathrm{NP}$, $+\mathrm{NSi}_{1}+\mathrm{PSi}$, and +NPSi (ALL). Nutrient additions were chosen to stimulate algal growth by providing temporary relief from nutrient limitation, if present. Bottles were incubated at Alice Cove at ambient temperature, light, and water mixing conditions in a floating incubator covered with a neutral density screen to reduce light penetration by $50 \%$. The phytoplankton response index (PRI) was calculated as the difference between the maximum and initial biomass (measured as chl a) divided by the time taken to reach the maximum biomass. To incorporate experimental errors, the threshold for a significant PRI response was set at $\geq 140 \%$ of the control. At intervals of 6 to $8 \mathrm{~h}$, subsamples were removed for analysis in the FIRe. After $48 \mathrm{~h}$, subsamples were removed from each triplicate treatment for $\mathrm{chl} a$ and FIRe analysis. Nutrient limitation was interpreted from differential responses to specific treatments according to the definitions in Fisher et al. (1999).

\section{Statistical analyses and mapping}

Data were tested for statistical significance using linear regression analysis. Where appropriate, ANOVA was used to establish statistically significant differences with a probability threshold of 0.05 . Given that measured water quality and fluorescence parameters were not significantly different between years in Simpson Bay ( $p>0.05)$, we pooled these data. Contour maps were created by using Surfer Software Version 9.0 with default settings, including gridding with the kriging algorithm.

\section{RESULTS}

\section{Water column hydrography in Simpson Bay}

Hydrographic profiles of temperature, salinity, turbidity, and chl a collected over diurnal tidal cycles in June 2007 show that whilst there is some horizontal variability in the top $10 \mathrm{~m}$ when tidal fluctuations are 

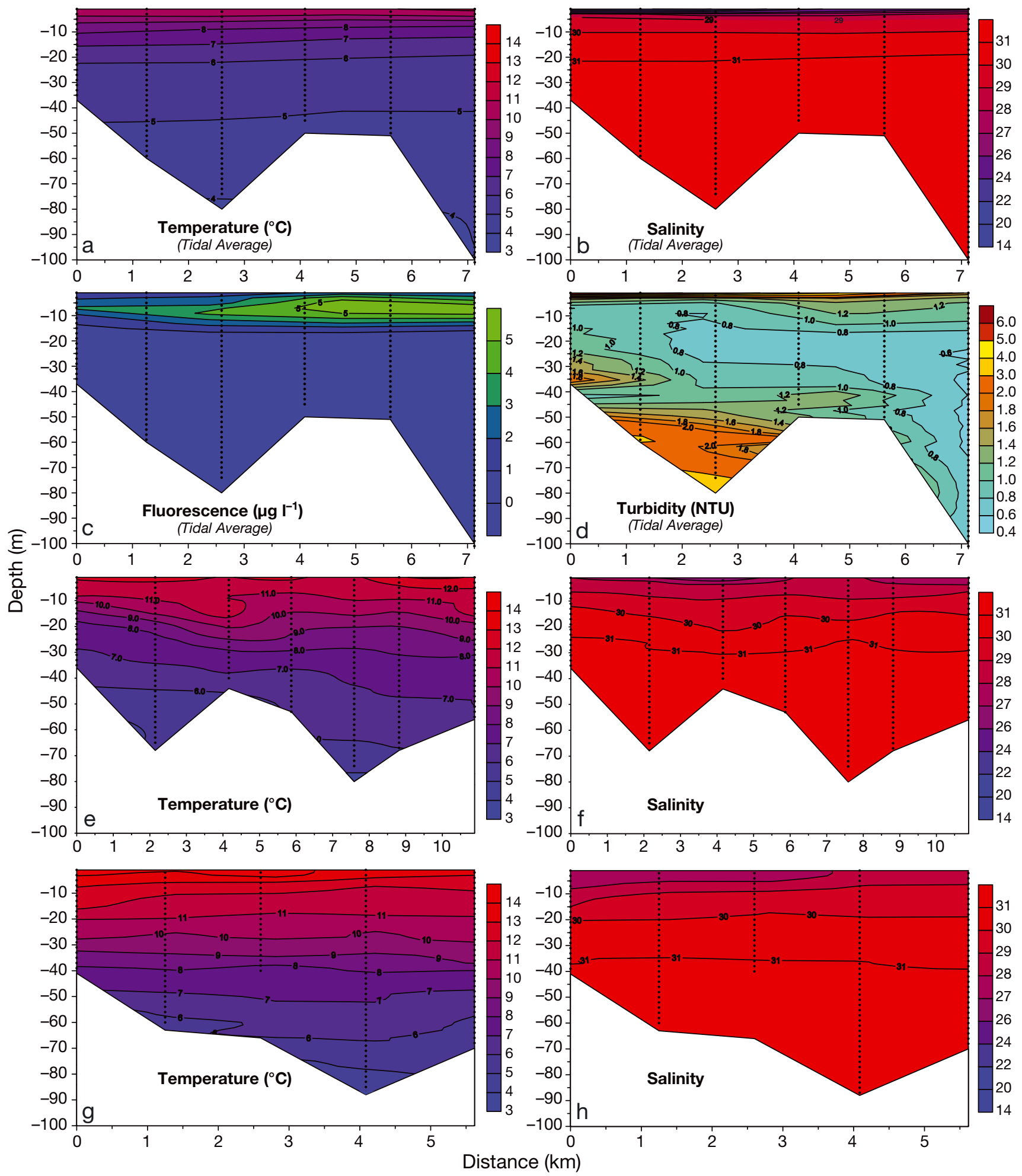

Fig. 2. Vertical water column sections of (a) temperature $\left({ }^{\circ} \mathrm{C}\right)$, (b) salinity, (c) chlorophyll fluorescence $\left(\mu \mathrm{g} \mathrm{l}^{-1}\right)$, and $(\mathrm{d})$ turbidity (NTU) measured in Simpson Bay in June 2007. These data represent tidal averages of measurements taken at 6 stations (SB7, SB7B, SB6B, SB5B, SB4B, and SB1C) along a transect extending from the delta in the northern arm to the mouth of the fjord (see Fig. 1). Vertical water column sections of (e) temperature $\left({ }^{\circ} \mathrm{C}\right.$ ) and (f) salinity measured in Sheep Bay in early July 1996 and in Simpson Bay (g and h, respectively). Stations sampled in Sheep Bay begin with SH1 in the upper basin and end with SH5 near the mouth (Fig. 1). Stations sampled in Simpson Bay were SB7, SB6, SB5, SB4, SB3, SB2, and SB1 (also shown in Fig. 1) 
Table 1. Hydrographic, biomass (as chl a), and fluorescence characteristics of the phytoplankton community measured in Simpson Bay (all years) and Sheep Bay (in 2006). We compiled all the data measured in the top $10 \mathrm{~m}$ of the water column in each bay and calculated the medians and standard deviations (SD). DO: dissolved oxygen; $F_{\mathrm{V}} / F_{\mathrm{M}}$ : variable to maximum fluorescence yields; $\sigma_{\mathrm{PSII}}$ : functional absorption cross-section for PSII; $\tau_{\mathrm{Qa}}$ : efficiency of the photosynthetic apparatus; $p$ : connectivity factor

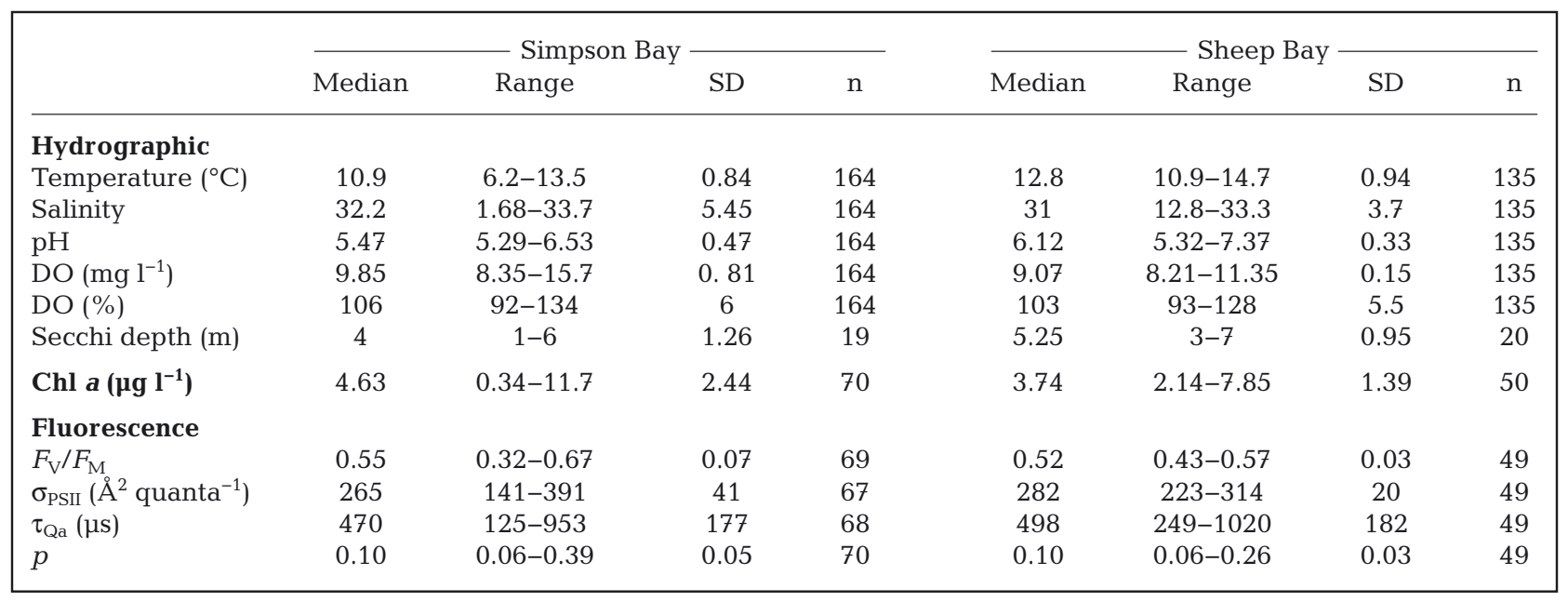

removed, it is not significant relative to what is taking place over the whole water column due to high stratification (Fig. 2a-d, Table 1). Below 25 m, temperatures were $<7^{\circ} \mathrm{C}$, salinities were $>30$, chl a was $<1.0 \mu \mathrm{g} \mathrm{l} \mathrm{l}^{-1}$, and turbidity was low but variable. The shallow layer with cooler temperatures and lower salinity waters results from freshwater runoff from the delta and numerous waterfalls located along the periphery of each basin. Highest chl a concentrations were measured in the upper $10 \mathrm{~m}$, near the mouth of the bay (Fig. 2c).

\section{Water column (top $10 \mathrm{~m}$ ) hydrography and spatial patterns in Simpson and Sheep Bays}

Water quality profiles in Simpson Bay measured in the top $10 \mathrm{~m}$ were similar between summers ( $p>0.05)$, therefore we summarized all findings in Table 1 . We found the range of temperatures and salinities was greater in Simpson Bay $\left(6.2\right.$ to $13.5^{\circ} \mathrm{C}$, 1.68 to 33.7, respectively) than in Sheep Bay (10.9 to $14.7^{\circ} \mathrm{C}, 12.8$ to 33.3 , respectively), but these parameters were not significantly different between the 2 bays ( $p>0.05)$. However, a freshwater/brackish lens of water (0 to 12) occurred near the delta of Simpson Bay (northern arm), as well as in areas immediately adjacent to significant waterfalls (Fig. 3a). The freshwater layer was typically found in the top 0.5 to $1.0 \mathrm{~m}$ near the delta area in Simpson Bay, but its spatial distribution varied among years, being larger in 2007 than in 2006 and 2008 (data not shown). The salinities and distribution of this water mass reflected the greater glacial freshwater inputs into Simpson Bay relative to Sheep Bay in 2006 (Fig. 3a). Sheep Bay was characterized by generally higher salinities throughout (Fig. 3a).

Dissolved oxygen concentrations ranged from 8.35 to $15.7 \mathrm{mg} \mathrm{l}^{-1}$, with no significant differences ( $\mathrm{p}>$ 0.05) among years (median: $9.85 \mathrm{mg} \mathrm{l}^{-1}$ ) in Simpson Bay (Table 1). Dissolved oxygen concentrations in Sheep Bay were similar (range: 8.21 to $11.35 \mathrm{mg} \mathrm{l}^{-1}$, median: $9.07 \mathrm{mg} \mathrm{l}^{-1}$ ) to those measured in all 3 years in Simpson Bay (Table 1). These dissolved oxygen concentrations are typical for productive marine and well mixed systems.

In general, there was more light penetration of the water column in Sheep Bay (median: $5.25 \mathrm{~m}$ ) than in Simpson Bay (median: $4 \mathrm{~m}$ ) based on Secchi depths (Table 1), but the differences between the 2 bays was not statistically significant $(p>0.05)$. While Secchi depths varied among stations between years in Simpson Bay, the range (1 to $6 \mathrm{~m}$ ) was similar to that measured in 2006.

In general, we found higher concentrations of chl a in the north and west of the bays, with lowest concentrations measured near the delta and highest toward the mouth (Fig. 3b). Chl a concentrations varied 35-fold across Simpson Bay, from 0.34 to $11.7 \mu \mathrm{g}$ $\mathrm{l}^{-1}$ (Fig. 3b), with a median value of $4.63 \mu \mathrm{g} \mathrm{l^{-1 }}$ (Table 1). Greater chl a concentrations were observed along the coastlines than in the central part of the Simpson Bay. This pattern is consistent with the spatial distribution inferred by fluorescence profiles shown in Fig. 2c. Chl a concentrations in Sheep Bay in 2006 were more heterogenous and ranged from 

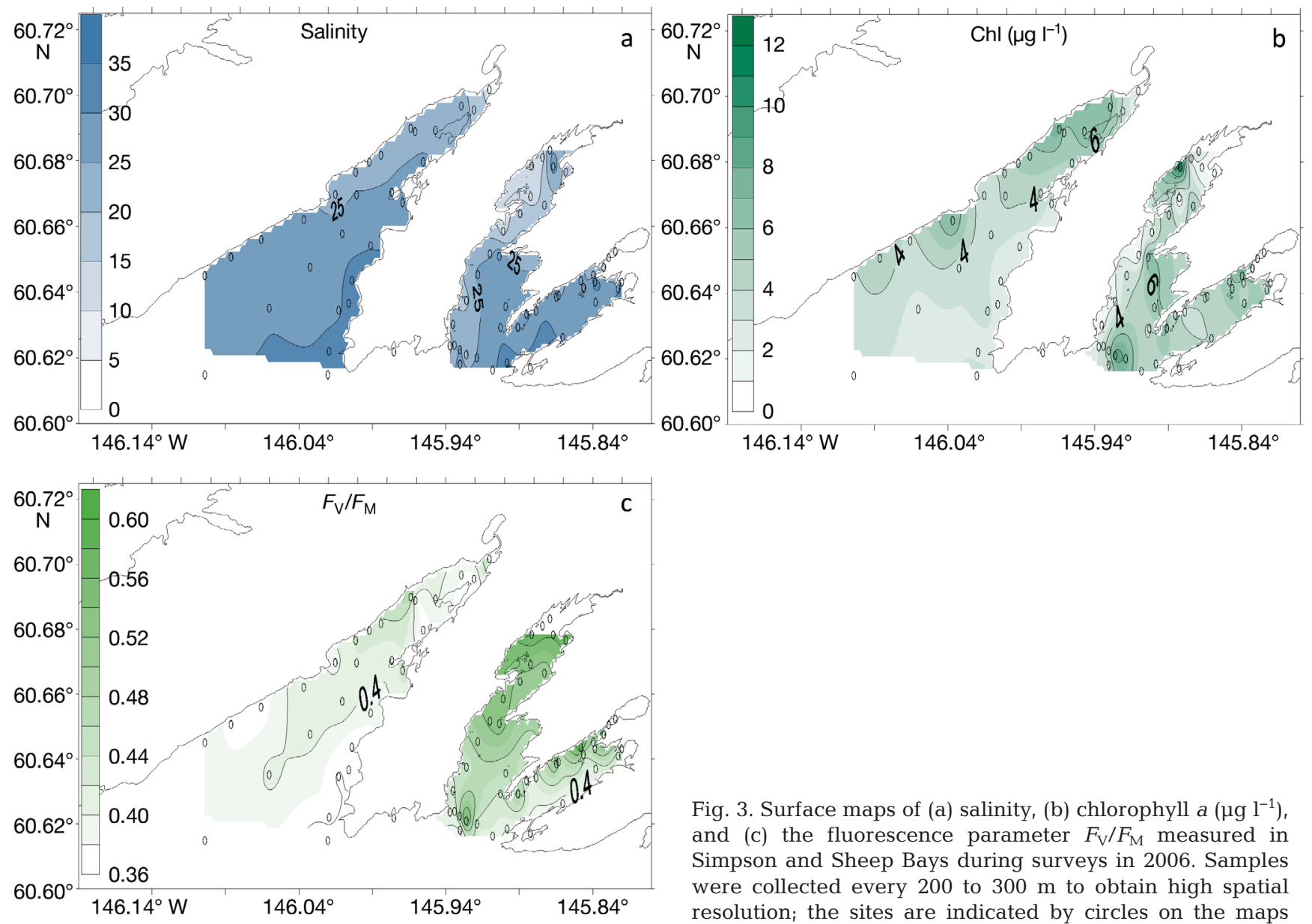

Fig. 3. Surface maps of (a) salinity, (b) chlorophyll a ( $\mu \mathrm{g} \mathrm{l}^{-1}$ ), and (c) the fluorescence parameter $F_{\mathrm{V}} / F_{\mathrm{M}}$ measured in Simpson and Sheep Bays during surveys in 2006. Samples were collected every 200 to $300 \mathrm{~m}$ to obtain high spatial resolution; the sites are indicated by circles on the maps

2.14 to $7.85 \mu \mathrm{g} \mathrm{l}^{-1}$. Median chl a was lower in Sheep Bay than in Simpson Bay ( $>$ 0.05) (Fig. 3b, Table 1).

\section{Water column (top $10 \mathrm{~m}$ ) and spatial patterns in FIRe-derived parameters in Simpson and Sheep Bays}

Highest $F_{\mathrm{V}} / F_{\mathrm{M}}$ values were measured in Simpson Bay, with higher ratios closer to the delta in the northern arm and along the coastline of the western basin (Fig. 3c). Lowest ratios were measured towards the mouth and in the eastern basin. $F_{\mathrm{V}} / F_{\mathrm{M}}$ ratios in surface waters were generally lower in Sheep Bay compared to Simpson Bay, ranging from 0.31 to 0.48 and 0.36 to 0.60 , respectively (Fig. 3c). However, when looking at ratios measured in both fjords in the top $10 \mathrm{~m}$ of the water column, median values were very similar (Table 1$) . F_{\mathrm{V}} / F_{\mathrm{M}}$ ratios, $\sigma_{\mathrm{PSII}} \tau_{\mathrm{Qa}}$ and $p$ values were not significantly correlated $(\mathrm{p}>0.05)$ with any of the water quality parameters measured simultaneously.
$\sigma_{\mathrm{PSII}}$ is sensitive to changes in both light and nutrient availability. While no spatial patterns or gradients were detected along the length of either fjord, we did find $\sigma_{\mathrm{PSII}}$ varied between Simpson (141 to $391 \AA^{2}$ quanta $^{-1}$ ) and Sheep Bays (223 to $314 \AA^{2}$ quanta $^{-1}$ ) (Table 1), with lower median values in the former relative to the latter. $\tau_{\mathrm{Qa}}$ was faster in Simpson Bay phytoplankton (median: $470 \pm 177 \mu \mathrm{s})$ compared to those in Sheep Bay (498 $\pm 182 \mu \mathrm{s})$ (Table 1), suggesting a greater efficiency of the photosynthetic apparatus present in Simpson Bay phytoplankton relative to those in Sheep Bay. While values were variable, median $p$ values $(0.10)$ were the same in both fjords (Table 1).

\section{Phytoplankton community composition}

We used major biomarker pigments associated with dominant phytoplankton taxa to determine the main groups in Simpson Bay in 2008 (Fig. 4). Fucoxanthin (diatoms), peridinin (dinoflagellates), zea- 


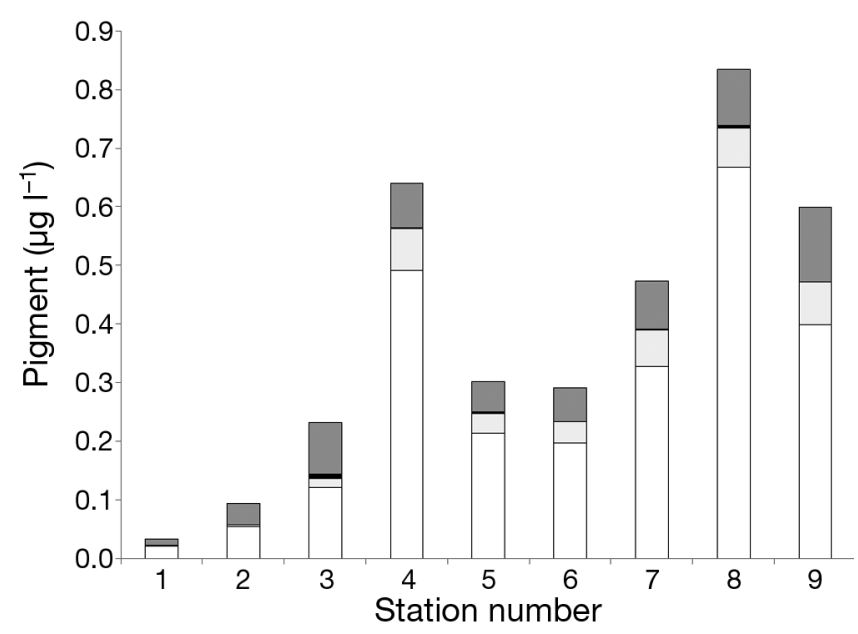

Fig. 4. Phytoplankton community composition measured in Simpson Bay in June 2008 at 9 stations. Stns 1 to 3 in the northern arm correspond, respectively, to SB7, SB7B, and a station between SB7B and SB5B (see Fig. 1). Stns 4 to 7 were located along the western basin and towards the mouth of the bay, corresponding to SB5B, SB4B, SB3B, and SB2D, respectively (see Fig. 1). We also included 2 stations in the eastern basin of Simpson Bay, Stns 8 and 9, which were located equidistant from the mouth to the head of this basin. Only major pigments are shown: fucoxanthin (white: diatoms), peridinin (light grey: dinoflagellates), zeaxanthin (black: cyanobacteria), and chlorophyll $b$ and prasinoxanthin (dark grey: green algae) xanthin (cyanobacteria), chl $b$, and prasinoxanthin (green algae) were measured at 9 stations. We labeled these stations 1 to 9 in Fig. 4; corresponding station numbers in Fig. 1 are given in the figure legend. Stns 1, 2 and 3 in the northern arm had the lowest pigment concentrations, whilst those towards the mouth of the bay in the western (Stns 6 and 7) and eastern basins (Stns 8 and 9) had 2-fold and 4fold higher concentrations, respectively. The heterogeneity observed with pigments is consistent with that for chl a (Fig. 3b). The most important groups appeared to be diatoms and dinoflagellates (Fig. 4); this is also consistent with the findings of plankton tows (data not shown). This observation supports the use of an $\mathrm{RC}_{\mathrm{PSII}} / \mathrm{chl}$ a of 0.002 in estimating primary production (see 'Materials and methods: Fluorescence measurements').

\section{Resource limitation assays}

From the delta (RLA1) to the mouth (RLA4) in Simpson Bay, salinity increased from 12.5 to 33.2 and Secchi depth increased from 1 to $6 \mathrm{~m}$ (Table 2). Nutrient concentrations measured prior to starting the

Table 2. Hydrographic, biomass (as chl a), nutrient, and fluorescence characteristics measured in the initial water samples from the 4 sites in Simpson Bay for the resource limitation assays (RLA; station codes in parentheses are those labeled in Fig. 1). DO: dissolved oxygen; DIN: dissolved inorganic nitrogen; P: inorganic phosphorus; other abbreviations as in Table 1 legend

\begin{tabular}{|c|c|c|c|c|}
\hline & $\begin{array}{c}\text { RLA1 }(\mathrm{SB} 7) \\
60.67^{\circ} \mathrm{N}, 145.87^{\circ} \mathrm{W} \\
\text { Delta }\end{array}$ & $\begin{array}{l}\text { RLA2 (SB6B) } \\
60.66^{\circ} \mathrm{N}, 145.90^{\circ} \mathrm{W} \\
\text { Shelton's buoy }\end{array}$ & $\begin{array}{l}\text { RLA3 (SB5B) } \\
60.64^{\circ} \mathrm{N}, 145.90^{\circ} \mathrm{W} \\
\text { Fireweed Bay }\end{array}$ & $\begin{array}{c}\text { RLA4 }(\mathrm{SB} 2 \mathrm{C}) \\
60.62^{\circ} \mathrm{N}, 145.92^{\circ} \mathrm{W} \\
\text { Mouth }\end{array}$ \\
\hline \multicolumn{5}{|l|}{ Hydrographic } \\
\hline Temperature $\left({ }^{\circ} \mathrm{C}\right)$ & 10.3 & 11.0 & 11.2 & 11.3 \\
\hline Salinity & 12.5 & 24.1 & 29.7 & 33.2 \\
\hline $\mathrm{pH}$ & 5.55 & 5.4 & 5.40 & 5.29 \\
\hline $\mathrm{DO}\left(\mathrm{mg} \mathrm{l}^{-1}\right)$ & 11.13 & 10.45 & 8.77 & 9.51 \\
\hline DO $(\%)$ & 107.4 & 109.4 & 98.4 & 102.4 \\
\hline Secchi depth (m) & 1 & 3.2 & 3 & 6 \\
\hline Chl a $\left(\mu \mathrm{gl}^{-1}\right)$ & 1.38 & 9.30 & 4.94 & 3.55 \\
\hline \multicolumn{5}{|l|}{ Nutrient } \\
\hline Nitrate $(\mu \mathrm{M})$ & 5.56 & 0.56 & 0.06 & 0.08 \\
\hline Nitrite $(\mu \mathrm{M})$ & 0.06 & 0.06 & 0.05 & 0.04 \\
\hline Ammonium $(\mu \mathrm{M})$ & 0.81 & 0.22 & 3.14 & 0.21 \\
\hline $\mathrm{DIN}(\mu \mathrm{M})$ & 6.44 & 0.84 & 3.25 & 0.32 \\
\hline$P(\mu \mathrm{M})$ & 0.19 & 0.10 & 0.27 & 0.19 \\
\hline Silicate $(\mu \mathrm{M})$ & 45.6 & 30.5 & 8.68 & 7.18 \\
\hline DIN:P & 33.6 & 8.8 & 11.9 & 1.7 \\
\hline DIN:Si & 0.14 & 0.03 & 0.37 & 0.04 \\
\hline \multicolumn{5}{|l|}{ Fluorescence } \\
\hline$F_{\mathrm{V}} / F_{\mathrm{M}}$ & 0.52 & 0.50 & 0.56 & 0.55 \\
\hline$\sigma_{\text {PSII }}\left(\AA^{2}\right.$ quanta $\left.^{-1}\right)$ & 391 & 349 & 245 & 259 \\
\hline$\tau_{\mathrm{Qa}}(\mu \mathrm{s})$ & 953 & 348 & 278 & 389 \\
\hline$p$ & 0.07 & 0.17 & 0.39 & 0.09 \\
\hline Predicted limiting resource & Light & $\mathrm{N}$ & $\mathrm{N}$ & $\mathrm{N}$ \\
\hline Measured limiting resource & $+\mathrm{ALL}$ & +NSi, +ALL & $+\mathrm{NP},+\mathrm{ALL}$ & $+\mathrm{NP},+\mathrm{ALL}$ \\
\hline
\end{tabular}



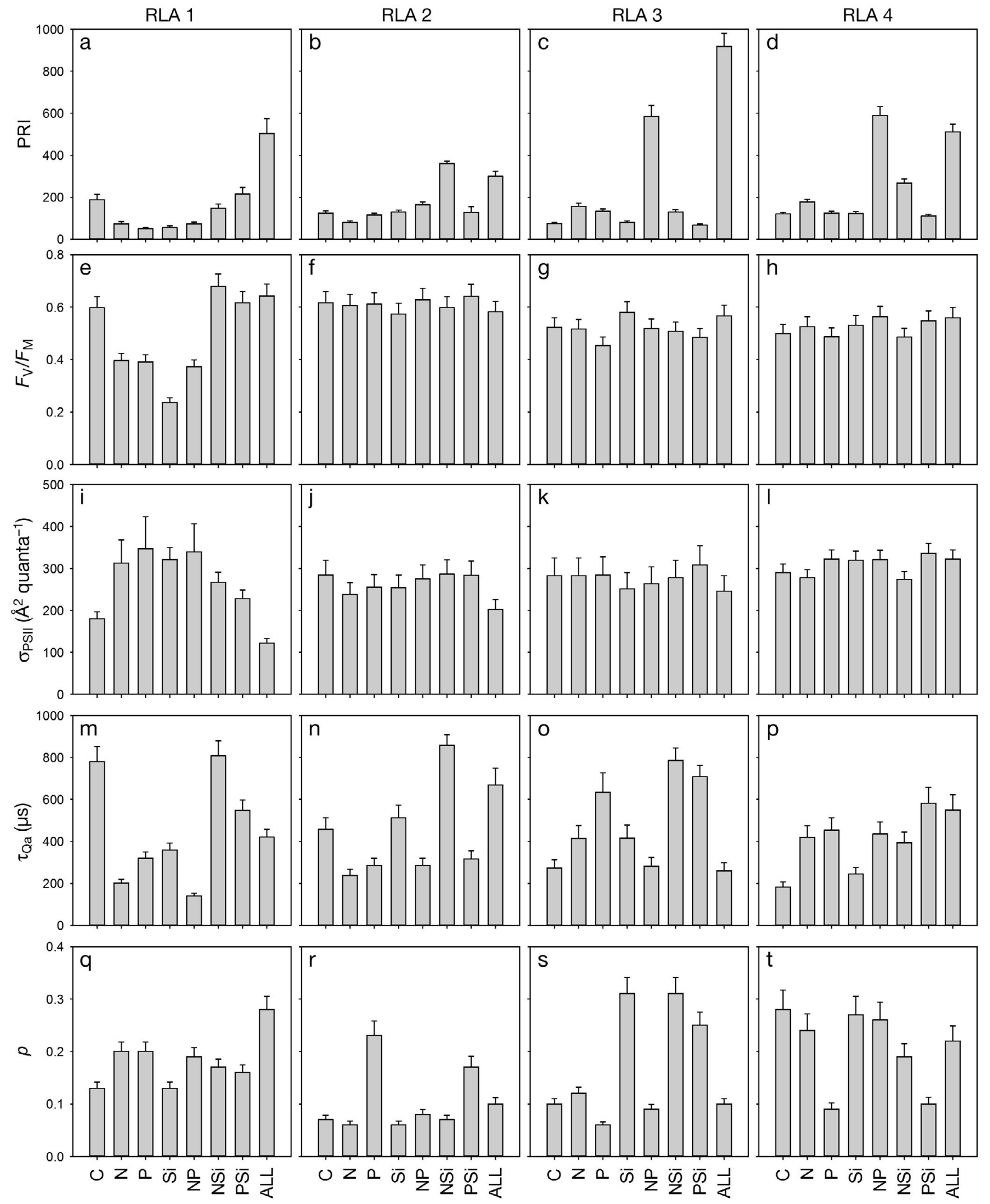

Fig. 5. Four resource limitation assays (RLA1-RLA4) were conducted in Simpson Bay during 2008 to determine if light or nutrient(s) (N, P, Si and combinations; C: control, no addition) were limiting phytoplankton growth (a-d). The phytoplankton response index (PRI) is used to normalize changes in biomass in each treatment so that all results are comparable between assays, while fluorescence parameters (see Table 1 for definitions) provide information on their physiological responses: (e-h) 
RLAs revealed a decrease in nitrate (5.56 to $0.08 \mu \mathrm{M})$, silicate (45 to $7.2 \mu \mathrm{M})$, DIN (6.44 to $0.32 \mu \mathrm{M}), \mathrm{DIN}$ :P ratios (33 to 1.68), and DIN:Si ratios (0.14 to 0.04 ) (Table 2) in moving from the delta to the mouth of the bay. P values were variable, but not significantly different between stations, ranging from 0.10 to $0.27 \mu \mathrm{M}$ (Table 2). These nutrient concentrations did not vary significantly from those found by A. S. McInnes et al. (unpubl. data) for Simpson Bay from 2008 to 2010.

In the 'initial' samples, that is, before treatments were started, $F_{\mathrm{V}} / F_{\mathrm{M}}$ was similar at all 4 stations $(0.53$ $\pm 0.02)$, but chl a concentrations varied from 1.38 to $9.3 \mathrm{\mu g} \mathrm{l}^{-1}$ (Table 2). Phytoplankton in the delta had significantly greater $\sigma_{\text {PSII }}\left(391 \AA^{2}\right.$ quanta $^{-1}$ ) and slower $\tau_{\mathrm{Qa}}(953 \mu \mathrm{s})$ than those in the rest of Simpson Bay (349 to $245 \AA^{2}$ quanta $^{-1}$ and 278 to $389 \mu \mathrm{s}$, respectively) (Table 2 ).

After $48 \mathrm{~h}$, phytoplankton in RLA1 responded most significantly when all nutrients were added, that is, the greatest PRI index (505) was calculated in the ALL treatments (Fig. 5a). The addition of 1 nutrient (i.e. $\mathrm{N}$ or $\mathrm{P}$ or $\mathrm{Si}$ ) did not stimulate growth or an increase in $F_{\mathrm{V}} / F_{\mathrm{M}}$ beyond what was observed in the control (C) treatments. There was no evidence of light limitation either, despite our prediction for phytoplankton found in the delta. In the control,

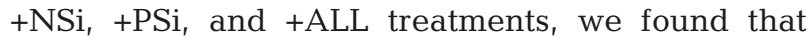
$F_{\mathrm{V}} / F_{\mathrm{M}}$ and $p$ increased to $\sim 0.60$ and $\sim 0.18$, while $\sigma_{\mathrm{PSII}}$ decreased to $\sim 250 \AA^{2}$ quanta $^{-1}$ relative to the initial sample (Table 1, Fig. 5e,q,i respectively).

We found +NSi and +ALL treatments had the greatest PRI indices in RLA2 (360 and 300, respectively), indicating co-limitation by $\mathrm{N}$ and $\mathrm{Si}$ as the $+\mathrm{N}$ and $+\mathrm{Si}$ alone treatments did not produce a PRI which was significantly different from the control ( $p>0.05$ ) (Fig. 5b). While $F_{\mathrm{V}} / F_{\mathrm{M}}$ increased and $\sigma_{\mathrm{PSII}}$ decreased in all treatments relative to the initial values, changes in $\tau_{\mathrm{Qa}}$ and $p$ were treatment-specific (Fig. $5 f, j, n, u$ ). For example, $\tau_{\mathrm{Qa}}$ in the $+\mathrm{NSi}$ and + ALL treatments was significantly higher $(p<0.05)$ than the control treatment after $48 \mathrm{~h}$.

The strongest response to nutrient additions was measured in the +NP and +ALL treatments in the RLA3 and RLA4 bioassays (PRI indices: $>500$ ) performed with surface water collected from the western basin and the mouth, respectively (Fig. 5c,d). There was also evidence of $\mathrm{N}$ and $\mathrm{Si}$ co-limitation at the mouth of Simpson Bay given the +NSi treatment was significantly higher than the control, but the $+\mathrm{N}$ and + Si treatments were not (Fig. 5d). While variable, $F_{\mathrm{V}} / F_{\mathrm{M}}$ and $\sigma_{\mathrm{PSII}}$ did not differ greatly after the $48 \mathrm{~h}$ incubation period in RLA3 and RLA4 across all treat- ments and the control (Fig. 5g,h \& k, l, respectively). The average ratio of the quantum yield of photochemistry and $\sigma_{\text {PSII }}$ were $0.52 \pm 0.03$ and $291 \pm 25 \AA^{2}$ quanta $^{-1}$, respectively, at the start of the RLAs (Table 2). These were not different from the values measured in the initial water sample (Table 1). The minimum turnover time of electron transfer between reaction centers $\left(\tau_{\mathrm{Qa}}\right)$ and the connectivity factor $(p)$ did not appear to follow any particular pattern in responding to nutrient treatments, nor did they have a location-dependent pattern (Fig. 5). This reflects the complex response of phytoplankton balancing changes in growth, nutrient acquisition, and light.

\section{DISCUSSION}

Given that the northern subarctic regions of the Pacific Ocean are getting warmer and fresher, that glacial melt has been increasing in the last $50 \mathrm{yr}$, summer precipitation and temperatures are expected to rise, and stratification is predicted to increase further in the coming decades due to climate change, we need studies that examine the current biological and ecological status of pristine systems such as the fjords in PWS (Royer \& Grosch 2006, IPCC 2007, Spies 2007, US Global Change Research Program 2009, Haufler et al. 2010). The finding of larger sea otter populations in Simpson Bay relative to Sheep Bay prompted questions concerning the food supply for these top-level predators (e.g. Lee et al. 2009) and a recent study of the food web structure in Simpson Bay (A. S. McInnes et al. unpubl. data). In these highlatitude subarctic ecosystems, phytoplankton blooms are an essential nutritional source for higher trophic levels (Ziemann et al. 1990, Kline 1999, 2001, A. S. McInnes et al. unpubl. data). Bivalves including clams, cockles, scallops, and mussels, which form the basis of the sea otter diet, are directly reliant on phytoplankton activity for growth and reproduction.

Numerical modeling in combination with field methods conducted by Eslinger et al. (2001) revealed that the seasonal cycle of phytoplankton production in PWS is primarily determined by winds and air temperatures during a short, critical period each spring. Due to their protected nature, small fjords and bays may lead the central basin of PWS in the timing of spring blooms, and exhibit incipient chl a concentrations ranging from 5 to $7 \mathrm{\mu g} \mathrm{l}^{-1}$ by late March (Gay \& Vaughan 2001). Partitioning of that production between the water column and benthic consumers defines responses of the higher trophic components of the system (Iverson et al. 1974, Sam- 
brotto \& Lorenzen 1986, Eslinger et al. 2001). While studies have documented the physical oceanography in Simpson Bay (Gay \& Vaughan 2001, Gay 2011), little is known about the base of the food web, the phytoplankton. This study represents an effort to assess phytoplankton activity and the factors controlling it in these remote fjords in PWS, Alaska. As a result of climate change, we anticipate summer phytoplankton productivity will be altered due to shifts in the timing and magnitude of ocean warming and retreating glaciers, precipitation, freshwater discharge, and stratification.

\section{Factors regulating phytoplankton activity}

\section{Hydrography}

Early summer (June) hydrography in Simpson Bay did not vary significantly between 2006 and 2008 despite potential interactions between local climate, advection of allochthonous glacial water, and vertical mixing from winds and tides (Gay 2011, present study). During each field season, we measured similar water quality characteristics in Simpson Bay (Table 1). The notable difference was the spatial and vertical extent of a freshwater lens in the delta located in the upper northern arm (Figs. 1 \& 2). The extent and distribution of low-salinity waters is influenced by snow melts and annual precipitation patterns.

Our findings are consistent with an earlier study (1994 to 1997) conducted by Gay \& Vaughan (2001) in Simpson Bay which found mean summer surface temperature over the bay varied between 12.9 and $13.9^{\circ} \mathrm{C}$, but our salinities were higher (median: 32) than the 17.6 to 24.1 previously reported. For the same period, the average air temperatures during summer (June to August) ranged from 12.9 to $14.3^{\circ} \mathrm{C}$ in PWS, while annual precipitation varied 2.5 -fold from 205 to $501 \mathrm{~cm}$ (Gay \& Vaughan 2001). In general, temperatures and salinities were higher in Sheep Bay, reflecting the paucity of freshwater inputs as waterfalls or glacial melt in this fjord relative to Simpson Bay (see also 'Decadal changes in hydrography' below).

We found phytoplankton standing stocks in Simpson and Sheep Bays were generally low, but similar in magnitude to those previously reported in PWS and in the nearby Auke Bay in the summer (Ziemann et al. 1990, Eslinger et al. 2001). Median values of 4.63 and $3.74 \mu \mathrm{g} \mathrm{chl} \mathrm{a}{ }^{-1}$ were measured in Simpson and Sheep Bays, respectively, but the range was more than 10-fold (see Fig. 3b, Table 1). Iverson et al.
(1974) reported that small increases in phytoplankton biomass in early summer occurred due to wind and/or tidal mixing temporarily reducing surface stratification and increasing euphotic zone nutrients. Later in the summer, surface layer stratification strengthens with runoff and seasonal heating, so that phytoplankton stocks may be reduced (Eslinger et al. 2001). Ziemann et al. (1990) also found that increases in biomass and primary productivity in early summer were triggered by nutrient resupply to the photic zone in nearby Auke Bay due to wind-driven vertical mixing. A. S. McInnes et al. (unpubl. data) found a reoccurring Noctiluca bloom in Simpson Bay each June and a smaller diatom bloom later in the summer. The late season diatom increase at Simpson Bay is perhaps associated with increased storm activity in mid- to late summer (Gay \& Vaughan 2001, Gay 2011) or it may be associated with an enhanced or suppressed late glacial melt pulse and subsequent remixing of nutrients into the euphotic zone.

Ziemann et al. (1990) reported that the majority of the phytoplankton biomass was present in the upper $15 \mathrm{~m}$ of the water column in PWS. This is consistent with our observations (Fig. 2) and those of Gay (2011). The vertical distribution of fluorescence parameters within the upper layer of these fjords reflects the influence of wind-driven mixing on phytoplankton. The mixing rate was sufficient to cause phytoplankton to be moved through the vertical light gradient faster than they could alter their photosynthetic apparatus, such that these parameters were uniform with depth (not shown). Moore et al. (2003) also found vertical distributions of phytoplankton were related to the hydrology and physical forcing in the English Channel. While these 2 environments are quite different, the physiological response of phytoplankton is similar and reflects the ubiquitous strategies.

\section{Biology}

The maximum quantum efficiency of PSII of darkacclimated samples reflects the physiological acclimation of phytoplankton to their environment on a range of scales (Kolber et al. 1998, Parkhill et al. 2001). Typically $F_{\mathrm{V}} / F_{\mathrm{M}}$ in nutrient-replete and highly productive regions is 0.65 , while in oligotrophic regions it can be $<0.4$ (e.g. Falkowski \& Kolber 1995, Babin et al. 1996). Low values of $F_{\mathrm{V}} / F_{\mathrm{M}}$ in this respect are thought to be a biophysical consequence of nutrient limitation on the photosynthetic apparatus so that the addition of nutrients can lead to an increase in this ratio on a range of time scales (e.g. Parkhill et al. 
2001, Sylvan et al. 2007). Light-limitation, on the other hand, has been associated with higher than average $F_{\mathrm{V}} / F_{\mathrm{M}}$ (Smyth et al. 2004, Quigg et al. 2006). In Simpson and Sheep Bays, $F_{\mathrm{V}} / F_{\mathrm{M}}$ ranged from 0.32 to 0.67 and 0.43 to 0.57 , respectively, indicating these systems are possibly nutrient but not light limited. Further support for this hypothesis comes from the observed increase in $F_{\mathrm{V}} / F_{\mathrm{M}}$ in the resource limitation assays (Fig. 5).

While studies investigating phytoplankton responses in the natural environment and/or to resource (nutrient) limitation assays are common at lower latitudes (e.g. Chesapeake Bay, USA: Fisher et al. 1999; Gulf of Mexico, USA: Sylvan et al. 2007, Quigg et al. 2011; Moreton Bay, Australia: Quigg et al. 2008; Gulf of Aqaba, Israel: Suggett et al. 2009), there is a paucity of studies for ecosystems at higher latitudes. Previous studies in PWS found phytoplankton were $\mathrm{N}$ and/or Fe limited in the summer (references in PICES 2004). Phytoplankton were found to be frequently N limited in the summers of 1985 to 1989 in Auke Bay (Laws et al. 1988, Ziemann et al. 1990). These earlier studies revealed that light did not limit phytoplankton growth in early summer. While previous reports found phytoplankton populations to be limited by 1 nutrient (e.g. Ziemann et al. 1990, Eslinger et al. 2001, PICES 2004), we actually measured co-limitation by nitrate plus either silicate or phosphorus, and found this co-limitation to vary along a gradient from the delta to the mouth of Simpson Bay (Table 2). The finding of co-limitation by silicate has important implications for diatom standing stocks given that they make up the largest fraction ( $~ 50 \%)$ of the phytoplankton community in this fjord (Fig. 4) and in PWS in the summer (Ziemann et al. 1990).

$\sigma_{\text {PSII }}$ and $\tau_{\text {Qa }}$ provide a framework for understanding how phytoplankton adjust to their environment. Changes in $\sigma_{\mathrm{PSII}}$ require rearrangement of the photosynthetic apparatus and so can occur on short time scales. Prior to conducting RLAs, $\sigma_{\mathrm{PSII}}$ were larger and $\tau_{\mathrm{Qa}}$ were slower in the delta relative to the mouth of the bay. For $\sigma_{\text {PSII }}$ in particular, this mirrors the change in Secchi depth along this same gradient (Table 2). Phytoplankton growing in surface waters or those with a deep Secchi had smaller $\sigma_{\text {PSII }}$ values relative to those growing at greater depths or waters with a shallow Secchi reading. The broader range in $\sigma_{\mathrm{PSII}}$ in Simpson relative to Sheep Bay (Table 1) is consistent with the range in Secchi depths, although significant correlation was found. At the end of the RLAs, $\sigma_{\mathrm{PSII}}$ were generally smaller in all treatments, reflecting phytoplankton responses to increased nutrient availability (Kolber et al. 1998).
We found $\tau_{\mathrm{Qa}}$ to be highly variable in the phytoplankton present in Simpson and Sheep Bays (Table 1) and at the end of the RLAs in all treatments (Fig. 5). Given that $\tau_{\mathrm{Qa}}$ reflects the efficiency of the photosynthetic apparatus with faster time constants for more effective photosynthetic electron transfer on the acceptor side of PSII (Kolber et al. 1998, Gorbunov et al. 2000), we would predict faster $\tau_{\mathrm{Qa}}$ to reflect nutrient-replete photosynthesis versus nutrient-depleted responses. Clearly, the response is more complex than this prediction given we were not able to directly correlate (statistically) findings to either the water quality parameters or treatments.

\section{Primary productivity}

Although it was not possible to measure primary production using the ${ }^{14} \mathrm{C}$ method in these remote fjords and we found that the light/dark bottle method was insensitive (data not shown), we used the FIRe to estimate primary productivity. Essentially, to use the biophysical model of Kolber et al. (1998), several assumptions were made, as has been done in other studies (e.g. Suggett et al. 2001, Moore et al. 2003, Smyth et al. 2004, Corno et al. 2006, Quigg et al. 2012). First, as the photosynthetic unit size ( $\left.n_{\text {PSII }}\right)$ cannot be measured directly with the FIRe (or FRRF) but only by measuring $\mathrm{O}_{2}$ flash yields (e.g. Quigg et al. 2003, Suggett et al. 2004), we assumed a $n_{\text {PSII }}$ of $500 \mathrm{chl}$ a per PSII. This was based on observations of a diatom/dinoflagellate-dominated community in Simpson Bay (present study, A. S. McInnes et al. unpubl. data), as well as in nearby coastal areas in summer (Ziemann et al. 1990, Waite et al. 1992). Second, we assumed a photosynthetic quotient of $1.0 \mathrm{~mol} \mathrm{O}_{2} \mathrm{~mol}^{-1} \mathrm{C}$ (see Laws 1991). A further consideration came from Fuchs et al. (2002) who reported that phaeophytin concentrations in environmental samples accounting for $>30 \%$ of the total pigment present led to a reduction in $F_{\mathrm{V}} / F_{\mathrm{M}}$, and so to an under-estimation of primary productivity. Measured phaeophytin concentrations accounted for $11 \%$ $( \pm 7 \% \mathrm{SD})$ of the total pigment concentration in both Simpson and Sheep Bays. Previously Laws et al. (1988) had observed that phaeopigments averaged $20 \%( \pm 10 \% \mathrm{SD})$ of chl a concentrations in the euphotic zone of the nearby Auke Bay in 1985. Given this information, it appears that phaeophytin concentrations measured in this study would not contribute to lowering our measured $F_{\mathrm{V}} / F_{\mathrm{M}}$ ratios or negatively influence our estimates of primary productivity. 
Estimated primary productivity in surface waters was $0.73 \mathrm{mg} \mathrm{C}(\mathrm{mg} \mathrm{chl} \mathrm{a})^{-1} \mathrm{~h}^{-1}( \pm 0.23)$ and $0.67 \mathrm{mg} \mathrm{C}$ $(\mathrm{mg} \mathrm{chl} \mathrm{a})^{-1} \mathrm{~h}^{-1}( \pm 0.25)$ in Simpson and Sheep Bays, respectively (Fig. 6). Given that there are no studies we know of in which the FIRe (or FRRF) has been used at high latitudes, and for comparative purposes only, we found our calculated primary productivity values are similar to that detected using the FRRF at the oligotrophic Stn ALOHA $\left(22^{\circ} 45^{\prime} \mathrm{N}, 158^{\circ} 00^{\prime} \mathrm{W}\right)$ located in the subtropical North Pacific $(0.25 \mathrm{mg} \mathrm{C}$ [mg chl a $]^{-1} \mathrm{~h}^{-1}$ ) (Corno et al. 2006). They are also lower than those measured by Suggett et al. (2001) for a spring cyanobacterial bloom in the North Atlantic (2.4 to $4.25 \mathrm{mg} \mathrm{C}[\mathrm{mg} \mathrm{chl} \mathrm{a}]^{-1} \mathrm{~h}^{-1}$ ) and by Smyth et al. (2004) for a bloom in the Celtic Sea in May 2000 (1.4 to $2.8 \mathrm{mg} \mathrm{C}[\mathrm{mg} \mathrm{chl} \mathrm{a}]^{-1} \mathrm{~h}^{-1}$ ). This comparison reveals that our values are at least comparable to those performed in other oligotrophic regions and that we were not sampling during the main sub-

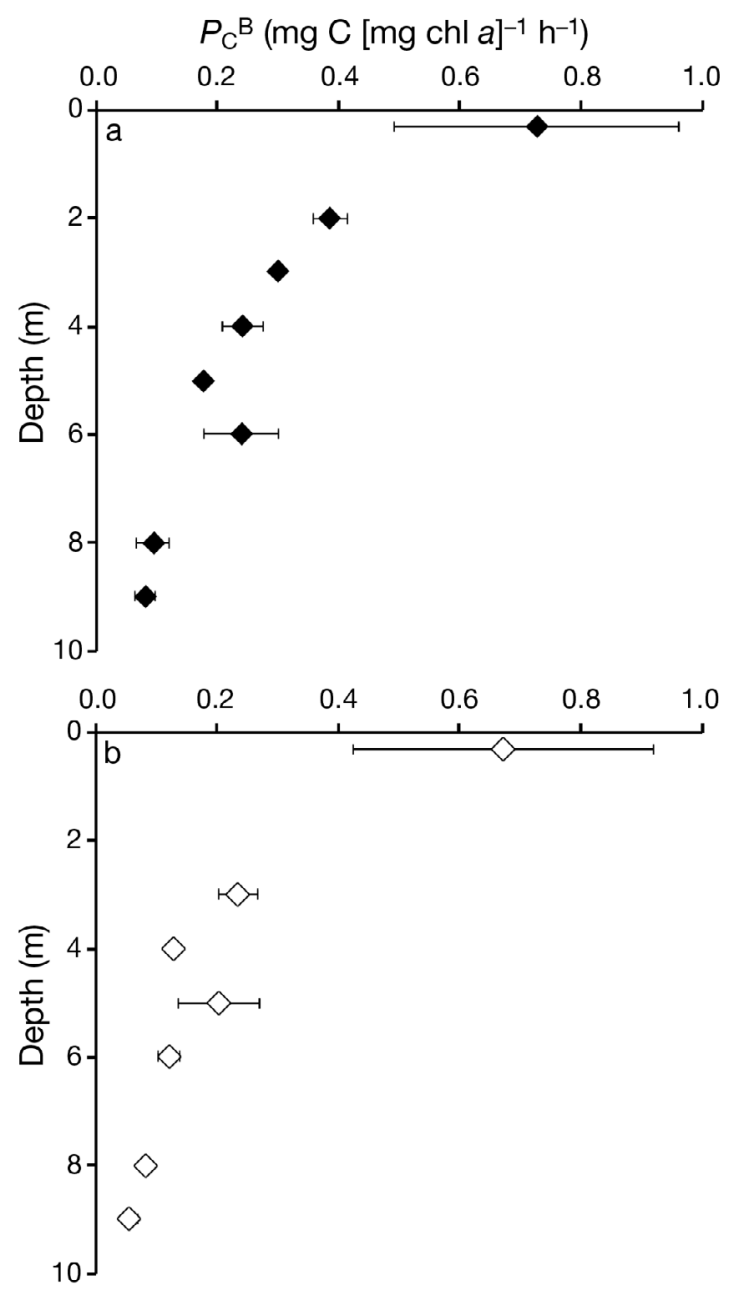

Fig. 6. Vertical profiles of primary productivity $\left(P_{\mathrm{C}}{ }^{\mathrm{B}} ; \mathrm{mg} \mathrm{C}[\mathrm{mg}\right.$ $\mathrm{chl} a]^{-1} \mathrm{~h}^{-1}$ ) estimated in (a) Simpson Bay and (b) Sheep Bay arctic bloom which typically occurs earlier in the year (Eslinger et al. 2001).

Integrated primary productivity varied from 0.72 to $1.08 \mathrm{~g} \mathrm{C} \mathrm{m}^{-2} \mathrm{~d}^{-1}$ in Simpson and Sheep Bays. Our estimates are comparable to those of Ziemann et al. (1991) measured during the summer in Auke Bay between 1985 and 1989 (0.1 to $1.5 \mathrm{~g} \mathrm{C} \mathrm{m}^{-2} \mathrm{~d}^{-1}$ ) and to those of Goering et al. (1973) measured using ${ }^{14} \mathrm{C}$ in nearby Port Valdez and other locations in the Valdez arm (1.5 to $\left.4.0 \mathrm{~g} \mathrm{C} \mathrm{m}^{-2} \mathrm{~d}^{-1}\right)$. These values are also comparable to those measured in other oligotrophic regions, such as in Moreton Bay, Australia (Quigg et al. 2008) and the Gulf of Aqaba, Israel (Suggett et al. 2009), but they are lower than those measured in eutrophic waters, such as the Chesapeake Bay, USA (e.g. Fisher et al. 1999), or the Gulf of Mexico, USA (Quigg et al. 2011).

\section{Decadal changes in hydrography}

Water column temperature and salinity changes define density stratification, which, in turn, affects vertical mixing and concurrently the light and nutrients available to phytoplankton. Temperaturesalinity profiles from Sheep and Simpson Bays measured in June of 2007 and July of 1996 are shown in Fig. 2a-d and Fig. 2e-h, respectively. Additional profiles collected in 1996 and 1997 and in 2007 and 2008 are presented in Gay \& Vaughan (2001) and Gay (2011), respectively. Differences in hydrography illustrate that water column structure has changed significantly between the 2 decades. These are not anomalies, but instead represent a trend. For example, heat and freshwater inputs were reciprocal to each other in these fjords in 1996. Sheep Bay also exhibited deeper vertical temperature and salinity gradients (deeper isotherms and isohalines), reflecting lower density stratification, and hence greater vertical mixing. In 1996 (and 1997) stratification did not become strong in Simpson Bay until August, occurring in conjunction with increased precipitation. In the late spring and early summer of 1996 and 1997, freshwater input in Simpson Bay occurred predominately from discharge of snowmelt and rainfall, but later in the season alpine glacial melting became a significant factor in freshening the inner basin of the fjord (Gay \& Vaughan 2001). During the latter season, allochthonous glacial water from the Rude River was also periodically advected westward into PWS. This water intrudes into the west basin of Simpson Bay by action of a flood tide jet across the sill at the mouth (Gay \& Vaughan 2001, Gay 2011). 
The Rude River water being mixed within the upper 20 to 30 m of Simpson Bay creates horizontal density gradients that enhance baroclinic inflows into the western basin by the tidal currents (Gay 2011). This results in vertical density gradients (shown as salinity in Fig. 2) that are well distributed over the water column within the western basin. In contrast, the northern basin exhibits the slower currents more typical of fjords, with flows occurring in 2 to 3 layers (Gay 2011). Stratification in this arm is also higher relative to the lower fjord due to greater surface freshening (Fig. 2).

Although it is likely that stratification at Sheep Bay also increased in 2007 (and 2008), like that in Simpson Bay (Fig. 2a-d), due to variation in watershed characteristics, it probably also had much lower freshwater input and deeper mixing in the later years as well. In contrast to observations from 1996, marked haline stratification in 2007 (and 2008) occurred by late June to early July. These differences reflect both earlier inputs of alpine melt water and higher snowfall in the latter years.

\section{CONCLUSIONS}

We report on the findings of hydrographic and physiological studies conducted in the summer in Simpson and Sheep Bays. Given the logistical challenges and remoteness of these bays, especially in the use of radioisotopic assays, we took advantage of the FIRe for assessing phytoplankton activity and to estimate primary productivity. The findings of this research will contribute to the development of food web models for these fjords and to the paucity of studies which examine the role of phytoplankton in this region (compared with the many studies on higher trophic levels, especially fisheries: e.g. references in Spies 2007). As with earlier studies in PWS (e.g. Laws et al. 1988, Eslinger et al. 2001), we found phytoplankton standing stocks responded to physical (wind mixing) and biological (nutrient) variability. Summer production is clearly an important contributor to the food supply, second only to the spring bloom, as has been reported in other high latitude and arctic systems. In addition, the western basin of Simpson Bay is markedly influenced by advection of water from Orca Bay (Gay 2011); thus, much of the primary production in the lower fjord basin may be due to allochthonous sources of nutrients. A comparison of the hydrography in Sheep Bay, collected in 1996, showed this fjord to be much more saline and the water column partially mixed in comparison to
Simpson Bay (Fig. 2). It is quite likely that haline stratification in this fjord increased markedly in 2007 (and 2008), similar to conditions within Simpson Bay. This, in addition to changing levels of freshwater input from melting glaciers in the northern Gulf of Alaska (Spies 2007, Gay 2011), could cause changes to the thermohaline circulation (and thus vertical mixing), which could, in turn, lead to upwelling of nutrient-rich waters in other locations. This would impact both the ecology and productivity of PWS and its subarctic fjords. Clearly further studies are required to fully understand the impacts of climate change, which are being felt especially strongly in this region (IPCC 2007, Spies 2007, Haufler et al. 2010), in order to develop a better ability to predict the downstream ecological affects that are going to impact the region in the coming decades.

Acknowledgements. This research was conducted as part of a Texas A\&M summer field course on Simpson Bay. We thank Fred Weltz for his introduction to the area and ideas for research projects. Skiff operators I. Davis, R. Wolt, and O. Lee were invaluable assets to completing this field work, as were the undergraduate students participating in the field course. A. Watson and M. Britton performed the chlorophyll analyses. This work was supported by the Texas Institute of Oceanography. The hydrographic data were collected during separate cruises sponsored by the Exxon Valdez Oil Spill Trustee Council. Three reviewers provided comments which improved the final manuscript.

\section{LITERATURE CITED}

Arar EJ, Collins GB (1997) U.S. Environmental Protection Agency method 445.0, in vitro determination of chlorophyll-a and pheophytin-a in marine and freshwater algae by fluorescence, Revision 1.2. US Environmental Protection Agency, National Exposure Research Laboratory, Office of Research and Development, Cincinnati, $\mathrm{OH}$

Babin M, Morel A, Claustre H, Bricaud A, Kolber ZS, Falkowski PG (1996) Nitrogen- and irradiance-dependent variations of the maximum quantum yield of carbon fixation in eutrophic, mesotrophic and oligotrophic marine systems. Deep-Sea Res I 43:1241-1272

> Corno G, Letelier RM, Abbott MR, Karl DM (2006) Assessing primary production variability in the North Pacific subtropical gyre: a comparison of fast repetition rate fluorometry and ${ }^{14} \mathrm{C}$ measurements. J Phycol 42:51-60

Cullen JJ, Davis RF (2003) The blank can make a big difference in oceanographic measurements. Limnol Oceanogr Bull 12:29-35

Dorado S, Rooker JR, Wissel B, Quigg A (2012) Isotope baseline shifts in pelagic food webs of the Gulf of Mexico. Mar Ecol Prog Ser 464:37-49

Eslinger DL, Cooney RT, Mcroy CP, Ward A and others (2001) Plankton dynamics: observed and modeled responses to physical conditions in Prince William Sound, Alaska. Fish Oceanogr 10:81-96 
Falkowski PG, Kolber ZS (1995) Variations in chlorophyll fluorescence yields in phytoplankton in the world oceans. J Plant Physiol 22:341-355

Fisher TR, Gustafson AB, Sellner K, Lacuture R and others (1999) Spatial and temporal variation in resource limitation in Chesapeake Bay. Mar Biol 133:763-778

Fuchs E, Zimmerman RC, Jaffe JS (2002) The effect of elevated levels of phaeophytin in natural waters on variable fluorescence measured from phytoplankton. J Plankton Res 24:1221-1229

Gay SM (2011) Physical oceanographic factors affecting productivity in juvenile Pacific herring nursery habitats. Final report for Exxon Valdez Oil Spill Restoration Project Number 070817. Prince William Sound Science Center, Cordova, AK

Gay SM, Vaughan SL (2001) Seasonal hydrography and tidal currents of bays and fjords in Prince William Sound, Alaska. Fish Oceanogr 10:159-193

Goering JJ, Patton CJ, Shiels WE (1973) Primary production. In: Hood DW, Shiels WE, Kelley EJ (eds) Environmental studies of Port Valdez. Institute of Marine Science Occasional Publications No. 3, University of Alaska, Fairbanks, AK, p 253-279

Gorbunov MY, Falkowski PG (2005) Fluorescence induction and relaxation (FIRe) technique and instrumentation for monitoring photosynthetic processes and primary production in aquatic ecosystems. In: Van der Est A, Bruce D (eds) Photosynthesis: fundamental aspects to global perspectives. Proceedings of the 13th International Congress of Photosynthesis, Montreal, Aug 29-Sep 3, 2004, Vol 2. Allen Press, Lawrence, KS, p 1029-1031

Gorbunov MY, Falkowski PG, Kolber ZS (2000) Measurement of photosynthetic parameters in benthic organisms in situ using a SCUBA-based fast repetition rate fluorometer. Limnol Oceanogr 45:242-245

Haufler JB, Mehl CA, Yeats S (2010) Climate change: anticipated effects on ecosystem services and potential actions by the Alaska Region, U.S. Forest Service. Ecosystem Management Research Institute, Seeley Lake, MT

Horner RA, Garrison DL, Plumley FG (1997) Harmful algal blooms and red tide problems on the U.S. West coast. Limnol Oceanogr 42:1076-1088

IPCC (Intergovernmental Panel on Climate Change) (2007) Climate change 2007: the physical science basis. In: Solomon S, Qin D, Manning M, Chen Z and others (eds) 4 th assessment report of the IPCC. Cambridge University Press, Cambridge, p 26-73

Iverson RL, Curl HC Jr, O'Connors HB Jr, Kirk D, Zakar K (1974) Summer phytoplankton blooms in Auke Bay, Alaska driven by wind-mixing of the water column. Limnol Oceanog 19:271-278

Julius SH, West JM (eds) (2008) Preliminary review of adaptation options for climate sensitive ecosystems and resources. US Climate Change Science Program and the Subcommittee on Global Change Research. Final Report Synthesis and Assessment Document 4.4

Kline TC Jr (1999) Temporal and spatial variability of ${ }^{13} \mathrm{C} /{ }^{12} \mathrm{C}$ and ${ }^{15} \mathrm{~N} /{ }^{14} \mathrm{~N}$ in pelagic biota of Prince William Sound, Alaska. Can J Fish Aquat Sci 56(Suppl 1):94-117

Kline TC Jr (2001) The trophic position of Pacific herring in Prince William Sound, Alaska based on their stable isotope abundance. In: Funk F, Blackburn J, Hay D, Paul AJ, Stephenson R, Toresen R, Witherell D (eds) Herring: expectations for a new millenium. AK-SG-01-04. Univer- sity of Alaska Sea Grant, Fairbanks, AK, p 69-80

Kolber ZS, Prasil O, Falkowski PG (1998) Measurements of variable chlorophyll fluorescence using fast repetition rate techniques: defining methodology and experimental protocols. Biochim Biophys Acta 1367:88-106

Kromkamp JC, Forster RM (2003) The use of variable fluorescence measurements in aquatic ecosystems: differences between multiple and single turnover measuring protocols and suggested terminology. Eur J Phycol 38: 103-112

Laws E (1991) Photosynthetic quotients, new production and net community production in the open ocean. Deep-Sea Res A 38:143-167

> Laws E, Bienfang P, Ziemann D, Conquest L (1988) Phytoplankton population dynamics and the fate of production during the spring bloom in Auke Bay, Alaska. Limnol Oceanogr 33:57-65

> Lee OA, Olivier P, Wolt R, Davis RW, Weltz F (2009) Aggregations of sea otters feeding on fish eggs and kelp in Prince William Sound, Alaska. Am Midl Nat 161:401-405

> Moore CM, Suggett D, Holligan PM, Sharples J and others (2003) Physical controls on phytoplankton physiology and production at a shelf sea front: a fast repetition-rate fluorometer based field study. Mar Ecol Prog Ser 259: $29-45$

Noll CJ, Dellapenna TM, Gilkinson A, Davis RW (2009) A high resolution geophysical investigation of sediment distribution controlled by catchment size and tides in a multi-basin turbid outwash fjord: Simpson Bay, Prince William Sound, Alaska. Geo-Mar Lett 29:1-16

> Parkhill JP, Maillet G, Cullen JJ (2001) Fluorescence-based maximal quantum yield for PSII as a diagnostic of nutrient stress. J Phycol 37:517-529

PICES (North Pacific Marine Science Organisation) (2004) Marine ecosystems of the North Pacific. PICES Spec Pub, North Saanich, BC. Available at www.pices.int/publications/special_publications/NPESR/2004/npesr_2004.aspx

> Quigg A, Beardall J, Wydrzynski T (2003) An investigation of the photosynthetic $\mathrm{O}_{2}$-evolving reactions in two marine microalgae as a function of the photon flux during growth. Funct Plant Biol 30:301-308

Quigg A, Kevekordes K, Raven JA, Beardall J (2006) Limitations on microalgal growth at very low photon fluence rates: the role of energy slippage. Photosynth Res 88: 299-310

Quigg A, Kevekordes K, Phillips JA (2008) Ecophysiological status of nine species of macroalgae and seagrasses in Moreton Bay, Queensland, Australia. In: Davie PJF, Phillips JA (eds) Proceedings of the 13th international marine biological workshop, the marine fauna and flora of Moreton Bay, Queensland. Mem Qld Mus 54:391-403

- Quigg A, Sylvan JB, Gustafson AB, Fisher TR, Tozzi S, Ammerman JW (2011) Going west: phosphorus limitation of primary production in the northern Gulf of Mexico and the importance of the Atchafalaya River. Aquat Geochem 17:519-544

Quigg A, Kotabová E, Jarešová J, Kaňa R and others (2012) Photosynthesis in Chromera velia represents a simple system with high efficiency. PLoS ONE 7:e47036

> Royer TC (2005) Hydrographic responses at a coastal site in the northern Gulf of Alaska to seasonal and interannual forcing. Deep-Sea Res II 52:267-288

Royer TC, Grosch CE (2006) Ocean warming and freshening in the northern Gulf of Alaska. Geophys Res Lett 33: L16605, doi:10.1029/2006GL026767 
Sambrotto RN, Lorenzen CJ (1986) Phytoplankton and primary production. In: Hood DW, Zimmerman ST (eds) The Gulf of Alaska: physical environment and biological resources. University of Washington Press, Seattle, WA, p 249-284

Smyth TJ, Pembreton KL, Aiken J, Geider RJ (2004) A methodology to determine primary production and phytoplankton photosynthetic parameters from fast repetition rate fluorometry. J Plankton Res 26:1337-1350

Spies RB (2007) Long-term ecological change in the northern Gulf of Alaska. Elsevier, Amsterdam

Suggett DJ, Kraay GW, Holligan PM, Davey M, Aiken J, Geider RJ (2001) Assessment of photosynthesis in a spring cyanobacterial bloom by use of a fast repetition rate fluorometer. Limnol Oceanogr 46:802-810

Suggett DJ, MacIntyre HL, Geider RJ (2004) Evaluation of biophysical and optical determinations of light absorption by photosystem II in phytoplankton. Limnol Oceanogr Methods 2:316-332

Suggett DJ, Stambler N, Prášil O, Kolber Z and others (2009) Nutrient control of oceanic microbial growth during spring in the Gulf of Aqaba. Aquat Microb Ecol 56: $227-239$

Editorial responsibility: Katherine Richardson, Copenhagen, Denmark
Suggett DJ, Borowitzka MA, Prasil O (2010) Chlorophyll a fluorescence in aquatic sciences: methods and applications. Springer, Heidelberg

Sylvan JB, Quigg A, Tozzi S, Ammerman JW (2007) Eutrophication-induced phosphorus limitation in the Mississippi River plume: evidence from fast repetition rate fluorometry. Limnol Oceanogr 52:2679-2685

US Global Change Research Program (2009) Global climate change impacts in the United States. Cambridge University Press, New York, NY. Available at http://downloads. globalchange.gov/usimpacts/pdfs/alaska.pdf

Waite A, Bienfang P, Harrison P (1992) Spring bloom sedimentation in a subarctic ecosystem. II. Succession and sedimentation. Mar Biol 114:131-138

Ziemann DA, Conquest LD, Fulton-Bennett K, Bienfang PK (1990) Interannual variability in the Auke Bay phytoplankton. In: Ziemann DA, Fulton-Bennett K (eds) APPRISE - interannual variability and fisheries recruitment. The Oceanographic Institute, Honolulu, HI

Ziemann DA, Conquest LD, Olaizola M, Bienfang PK (1991) Interannual variability in the spring phytoplankton bloom in Auke Bay, Alaska. Mar Biol 109:321-334

Submitted: August 20, 2012; Accepted: December 13, 2012 Proofs received from author(s): March 29, 2013 